\title{
PEMBELAJARAN KIMIA DENGAN MODEL INKUIRI TERBIMBING MENGGUNAKAN MEDIA LABORATORIUM RIILDAN VIRTUIL DITINJAU DARI GAYA BELAJAR DAN KEMAMPUANAWAL
}

\author{
Diastono $^{1}$, Ashadi $^{2}$, dan Haryono ${ }^{3}$ \\ ${ }^{1}$ Magister Pendidikan Sains, Fakultas Keguruan dan Ilmu Pendidikan, Universitas Sebelas Maret \\ Surakarta, 57126, Indonesia \\ diastono98@yahoo.co.id \\ ${ }^{2}$ Magister Pendidikan Sains, Fakultas Keguruan dan Ilmu Pendidikan, Universitas Sebelas Maret \\ Surakarta, 57126, Indonesia \\ ashadi_uns@yahoo.com \\ ${ }^{3}$ Magister Pendidikan Sains, Fakultas Keguruan dan Ilmu Pendidikan, Universitas Sebelas Maret \\ Surakarta, 57126, Indonesia \\ hharyono52@yahoo.com
}

\begin{abstract}
Abstrak
Penelitian ini bertujuan untuk melihat pengaruh penggunaan metode pembelajaran inkuiri terbimbing dengan menggunakan media laboratorium riil dan laboratorium virtuil berupa media animasi, gaya belajar dan kemampuan awal serta interaksinya terhadap prestasi belajar. Penerapan inovasi pembelajaran sain yang lebih menarik, melibatkan siswa dalam proses inkuiri. Metode ini diterapkan juga sebagai upaya untuk memilih media pembelajaran yang sesuai untuk pokok bahasan tertentu. Sampel diambil dengan menggunakan metode random sampling yang terdiri dari empat kelompok, yaitu dua kelompok yang belajar dengan metode inkuiri terbimbing menggunakan media laboratorium riil dan dua kelompok yang belajar dengan metode inkuiri terbimbing menggunakan media laboratorium virtuill. Data yang terkumpul berupa gaya belajar dan kemampuan awal serta hasil belajar kimia. Hipotesis dianalisa dengan Uji Anava tiga jalan dengan desain faktorial $2 \times 2 \times 2$. Dari analisis data dapat disimpulkan : (1) Siswa yang belajar dengan metode pembelajaran inkuiri terbimbing menggunakan media laboratorium virtuil dengan media animasi mencapai prestasi belajar yang lebih baik dari siswa yang belajar dengan metode inkuiri terbimbing menggunakan media laboratorium riil. (2) Siswa yang memiliki gaya belajar visual memiliki prestasi belajar yang lebih baik dari siswa yang memiliki gaya belajar kinestetik. (3) Prestasi belajar siswa yang memiliki kemampuan awal tinggi lebih baik dari siswa yang memiliki kemampuan awal rendah. (4) Tidak ada interaksi antara media pembelajaran dengan gaya belajar terhadap prestasi belajar siswa. (5) Tidak ada interksi antara media pembelajaran dengan kemampuan awal terhadap prestasi belajar siswa. (6) Tidak ada interaksi gaya belajar dengan kemampuan awal terhadap prestasi belajar siswa. (7) Tidak adanya interaksi antara media pembelajaran, gaya belajar dan kemampuan awal terhadap prestasi belajar siswa.
\end{abstract}

Kata kunci : Inkuiri Terbimbing, Media laboratorium riil dan virtuil, Gaya Belajar, Kemampuan Awal, Prestasi Belajar Kimia.

\section{Pendahuluan}

Untuk meningkatkan mutu pendidikan, yang dapat dilakukan oleh guru di antaranya menentukan model pembelajaran yang sesuai dengan karakteristik materi pelajaran. Isi materi suatu pelajaran mempunyai karakteristik yang berbeda dengan materi pelajaran yang lain, bahkan materi dalam satu mata pelajaran bisa berbeda-beda karena perbedaan kompetensi dasar yang akan dicapainya. Kondisi kemampuan awal yang merupakan prasyarat untuk mempelajari materi tertentu perlu diperhatikan tingkat ketuntasannya karena materi dalam suatu pelajaran tidak bisa dipisahkan satu dengan yang lainnya. Setelah kedua hal tersebut terpenuhi, perlu diperhatikan penggunaan media pembelajaran yang tepat. 
Untuk membantu kemampuan siswa dalam meningkatkan kwalitas pemahaman materi pelajaran kimia diperlukan model pembelajaran dan media yang tepat. Model inkuiri terarah atau terbimbing (guided inquiry) bisa digunakan sebagai salah satu alternatif model pembelajaran yang dapat diterapkan untuk membantu siswa dalam memecahkan masalah ini. Dalam model inkuiri, siswa dilibatkan untuk aktif berfikir dan menemukan pengertian yang ingin diketahuinya (Suparno : 65). Dengan model inkuiri melalui eksperimen atau kerja lapangan, siswa dapat berkreasi menyusun pengetahuan dan ketrampilannya sendiri (Quitadamo, dkk : 328). Pada model inkuiri terarah atau terbimbing, guru banyak mengarahkan dan memberikan petunjuk baik melalui prosedur yang lengkap maupun pertanyaan-pertanyaan pengarahan selama proses berlangsung. Model inkuiri terarah sesuai untuk diterapkan pada kelompok siswa yang belum biasa mengalami model inkuiri untuk menghindari kebingungan dan menghindari kegagalan karena guru terlibat penuh.

Di samping penerapan model pembelajaran tersebut, efektifitas pembelajaran juga dipengaruhi oleh kondisi pribadi siswa. Dalam proses pembelajaran, seorang guru hendaknya memahami kepribadian siswa. Salah satu hal yang sering dilupakan oleh para guru adalah bahwa setiap anak dengan latar belakang berbeda mempunyai keunikan tersendiri dalam belajar. Mereka mempunyai cara masing-masing dalam memperoleh dan mengolah informasi. Cara ini disebut dengan gaya belajar (learning style).Gaya belajar merupakan sifat yang khas bagi setiap siswa. Perbedaan gaya belajar ini akan mempengaruhi daya serap siswa terhadap isi suatu materi pelajaran. Suatu model pembelajaran dan media pembelajaran bisa cocok untuk siswa dengan gaya belajar tertentu tetapi belum tentu cocok bagi siswa dengan gaya belajar yang lain.

Kebanyakan sistem pendidikan telah mengabaikan perbedaan individu yang ada di antara peserta didik, seperti kemampuan belajar, latar belakang pengetahuan, tujuan pembelajaran dan gaya belajar (Ford \& Chen, 2001). Sistem pendidikan umumnya menyediakan bahan ajar yang unik dan standar untuk semua peserta didik yang cenderung menguntungkan untuk mereka yang gaya belajar dan latar belakang pengetahuannya cocok dengan materi pengajaran. Jika gaya mengajar yang digunakan sangat cocok dengan gaya yang disukai siswa dalam memperoleh pengetahuan, belajar akan menjadi lebih mudah dan lebih alami, hasilnya meningkat dan waktu belajarnya berkurang (Rose, 1998). (dalam Franzoni dan Assar, 2009)

Dalam usaha memahami suatu materi, terutama material yang tidak bisa dilihat secara langsung, siswa perlu dibantu untuk memahami hal yang abstrak menjadi lebih konkrit. Pemilihan media belajar yang tepat diharapkan dapat membantu mengatasi hal tersebut. Media belajar yang dipilih oleh guru diusahakan dapat membantu siswa untuk memahami hal yang abstrak. Pemilihan ini perlu dipertimbangkan dengan baik oleh guru karena akan sangat menunjang proses pemahaman.

Kimia bersifat hirarkis, konsep yang sudah dipahami sebelumnya diperlukan untuk memahami konsep berikutnya. Dalam proses belajar tidak terlepas dari pengalaman dan pengetahuan yang sudah dipahami sebelumnya. Konsep yang sudah dipahami sebelumnya yang dibutuhkan untuk mempelajari materi berikutnya disebut kemampuan awal (prior knowledge).Dalam penelitian ini, penyusun akan meniliti efektifitas penggunaan media laboratorium (laboratorium riil) dan media animasi (laboratorium virtual) terhadap prestasi belajar kimia di SMA MTA Surakarta.

\section{Metode Penelitian}

Model penelitian yang digunakan dalam penelitian ini adalah eksperimen dengan mengambil dua kelompok secara acak, normal dan homogen berdasarkan data hasil pengukuran gaya belajar siswa dan kemampuan awal siswa yang berupa kemampuan materi pH larutan. 
Satu kelompok diberi perlakuan pembelajaran dengan model inkuiri terbimbing dengan media laboratorium riil sedangkan kelompok yang lain belajar dengan model pembelajaran inkuiri terbimbing dengan media laboratorium virtual yang berupa media animasi. Materi pelajaran yang diberikan pada kedua kelas sama, yaitu Larutan Buffer dan Hidrolisis Garam. Masing-masing kelompok ditinjau dari gaya belajar dan kemampuan awalnya.

\section{Variabel Penelitian}

1. Variabel bebas : Variabel bebas adalah model pembelajaran inkuiri terbimbing menggunakan media laboratorium riil dan inkuiri terbimbing menggunakan media laboratorium virtuil.

2. Variabel moderator/atribut : Variabel moderator dalam penelitian ini adalah gaya belajar siswa dan kemampuan awal siswa. Variabel gaya belajar pada awal penelitian terbagi menjadi gaya belajar visual, auditori dan kinestetik. Pada penelitian ini variable moderator gaya belajar visual dan kinestetik. Kemampuan awal siswa berupa kompetensi $\mathrm{pH}$ larutan yang dibagi atas kemampuan awal tinggi dan rendah.

3. Variabel terikat : Dalam penelitian ini peneliti mengambil variabel terikat berupa prestasi belajar Kimia Kompetensi Dasar Larutan Buffer dan Hidrolisis Garam.

Sampel dalam penelitian ini diambil dari semua kelas program MIPA kelas XI SMA MTA Surakarta Tahun pelajaran 2014/2015 yang terdiri dari 6 kelas dengan siswa sebanyak 166, terdiri dari 78 siswa putra dan 86 siswa putri.

\section{Instrumen Penelitian}

1. Instrumen pelaksanan penelitian yang digunakan untuk proses pembelajaran, berupa silabus, Rencana Program Pembelajaran (RPP), Lembar Kerja Siswa (LKS), program power point dengan animasi, dan laboratorium Kimia di SMA MTA.

2. Instrumen pengambilan data yang digunakan untuk pengambilan data prestasi belajar siswa yang berupa instrument tes hasil belajar Kimia untuk aspek kemampuan kognitif siswa.

3. Instrument pengambilan data gaya belajar siswa

Data kemampuan awal siswa berupa data nilai kompetensi dasar $\mathrm{pH}$ Larutan dari data nilai ulangan harian $\mathrm{KD}$ pH Larutan.

\section{Teknik Pengumpulan Data}

Teknik pengambilan data pada penelitian ini menggunakan teknik tes yaitu tes prestasi belajar materi Larutan Buffer dan Hidrolisis Garam. Identifikasi gaya belajar dilakukan dengan menggunakan angket. Kemampuan awal diambil dari dokumen yang dimiliki oleh guru pengampu yang berupa data nilai $\mathrm{KD} \mathrm{pH}$ Larutan. Sebelum pengambilan data, instrument diujicobakan terlebih dahulu untuk mengetahui validitas dan reabilitas instrument.

\section{Pengujian Instrumen}

Pengujian instrument tes prestasi belajar siswa pada materi Larutan Buffer dan Hidrolisis Garam meliputi:

1. Validitas : Uji validitas digunakan untuk menentukan ketepatan instrument dalam mengukur apa yang sebenarnya hendak diukur. Rumus yang digunakan untuk menghitung validitas adalah:

$$
r_{x y}=\frac{N \Sigma X Y-\left(\sum x\right)\left(\sum Y\right)}{\sqrt{\left(\left(N \Sigma X^{2}\right)-(\Sigma x)^{2}\right) x\left(\left(N \Sigma Y^{2}\right)-(\Sigma Y)^{2}\right)}}
$$

2. Reabilitas : Uji reabilitas digunakan untuk menilai keajegan atau untuk menilai suatu instrument tersebut reliabel atau tidak. Rumus yang digunakan adalah:

$r_{n}=\alpha=\left[\frac{n}{n-1}\right] x\left[1-\frac{\Sigma S i^{2}}{S t^{2}}\right]$

3. Uji taraf kesukaran : Menguji instrument dengan taraf kesukaran dilakukan untuk mengetahuai sejauh mana instrument itu dapat dikerjakan oleh siswa. Rumus yang digunakan untuk menghitung taraf kesukaran adalah :

$T K=\frac{(W L+W H)}{(n L+n H)} \times 100 \%$ 
4. Taraf Pembeda : Taraf pembeda digunakan pada instrument penelitian tes prestasi belajar untuk mengetahui sejauh mana tes prestasi tersebut dapat membedakan antara kelompok siswa berprestasi tinggi dan rendah. Rumus yang digunakan untuk mengukur taraf pembeda adalah :

$$
T P=\frac{(M H-M L)}{\sqrt{\frac{\left(\Sigma X_{1}^{2}+\Sigma X_{2}^{2}\right)}{n_{i}\left(n_{i}-1\right)}}}
$$

\section{Teknik Analisis Data}

Teknik analisa data yang digunakan dalam penelitian ini meliputi analisis varians dua jalan. Sebelum dilakukan uji anava terlebih dahulu akan dilakukan uji prasyarat berupa uji homogenitas dan uji normalitas data.

1. Uji Normalitas : Rumus yang digunakan adalah model Lilliefors Significance Correction dari Kolmogorov-Smirnov dengan bantuan computer program SPSS Release 16, yang dapat diurutkan sebagai berikut :

a. Hipotesis Normalitas

$\mathrm{H}_{\mathrm{o}}$ : Sampel berasal dari populasi yang tidak terdistribusi normal

$\mathrm{H}_{1}$ : Sampel berasal dari populasi yang terdistribusi normal

b. Taraf signifikansi yang digunakan adalah $\alpha=0,05$

c. Keputusan uji

Jika $\mathrm{L}_{\text {obs }}>\mathrm{L}_{\text {tabel }}$, maka $\mathrm{H}_{\mathrm{o}}$ diterima dan $\mathrm{H}_{1}$ ditolak

Jika $\mathrm{L}_{\mathrm{obs}}<\mathrm{L}_{\text {tabel }}$, maka $\mathrm{H}_{\mathrm{o}}$ ditolak dan $\mathrm{H} 1$ diterima

2. Uji homogenitas : Penghitungan yang digunakan adalah software program SPSS release 10 , yaitu Levene's Test of Equality of Error Variancesa. Setelah memenuhi syarat, maka data yang diperoleh akan diolah dengan uji statistik anava dengan menggunakan desain faktorial sebagai berikut :
Tabel 1. Desain Penelitian Faktorial 2 X 2 X 2

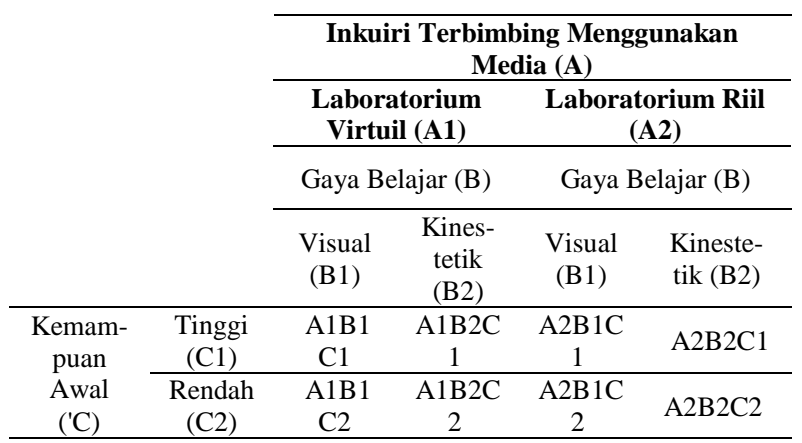

Data yang sudah dimasukkan dalam desain faktorial, kemudian diuji dengan ANAVA, dengan langkah-langkah sebagai berikut;

a. Mendeskripsikan data per kelompok

b. Uji normalitas data dengan Uji Kolmogorov Smirnov

c. Uji homogenitas data dengan Uji Lavene's Tes

d. Melakukan uji hipotesis dengan Uji Anava Tiga Jalur

e. Uji Lanjut Anava dengan Univariate Analysis of Variance yakni uji one way Anava dengan menggunakan model Befferoni

Setelah melakukan uji statistik ANAVA untuk menganalisis data, maka akan dilakukan uji lanjut ANAVA.

\section{Hasil Penelitian dan Pembahasan}

Tabel 2 menunjukkan frekwensi dan prosentase munculnya perolehan nilai siswa.

Tabel 2. Frekuensi Data Nilai Siswa

\begin{tabular}{cccc} 
No & Nilai & Frekwensi & Prosentase \\
\hline 1 & 20 & 3 & 2,34 \\
\hline 2 & 25 & 5 & 3,91 \\
\hline 3 & 30 & 6 & 4,69 \\
\hline 4 & 35 & 12 & 9,38 \\
\hline 5 & 40 & 10 & 7,81 \\
\hline 6 & 45 & 13 & 10,16 \\
\hline 7 & 50 & 19 & 14,84 \\
\hline 8 & 55 & 5 & 3,91 \\
\hline 9 & 60 & 19 & 14,84 \\
\hline 10 & 65 & 8 & 6,25 \\
\hline 11 & 70 & 8 & 6,25 \\
\hline 12 & 75 & 11 & 8,59 \\
\hline
\end{tabular}




\begin{tabular}{cccc}
\hline No & Nilai & Frekwensi & Prosentase \\
\hline 13 & 80 & 4 & 3,13 \\
\hline 14 & 85 & 2 & 1,56 \\
\hline 15 & 90 & 3 & 2,34 \\
\hline & Jumlah Data & 128 & 100,00
\end{tabular}

Secara keseluruhan dapat dijelaskan bahwa nilai terendah 20 dengan prosentase kemunculan sebesar 2,34\%, dan nilai tertinggi yang dicapai adalah 90 dengan prosentase kemunculan juga 2,34\%. Frekwensi terbesar munculnya nilai adalah 50 dan 60 masingmasing dengan prosentase $14,84 \%$.

Uji Lilliefors Significance Correction dari Kolmogorov-Smirov. Hasil pengujian normalitas data tersebut dipaparkan berikut ini: 1. Uji Normalitas Data Hasil Belajar Kelompok Siswa yang belajar dengan Strategi Pembelajaran Inkuiri Terbimbing Menggunakan Laboratorium Virtual dan Laboratorium Riil

Tabel 3. Data Hasil Tes Normalitas (Kolmogorov-Smirnov)

\begin{tabular}{|c|c|c|c|c|c|}
\hline No & Vari & & Statistik & $\mathrm{df}$ & Sig \\
\hline \multirow{2}{*}{1} & \multirow{2}{*}{$\begin{array}{l}\text { Media } \\
\text { Pembelajaran }\end{array}$} & Virtuil & 0,102 & 60 & 0,192 \\
\hline & & Riil & 0,105 & 68 & 0,059 \\
\hline \multirow[t]{2}{*}{2} & \multirow[t]{2}{*}{ Gaya Belajar } & Visual & 0,096 & 79 & 0,067 \\
\hline & & Kinestetik & 0,108 & 49 & 0,200 \\
\hline \multirow{2}{*}{3} & \multirow{2}{*}{$\begin{array}{l}\text { Kemampuan } \\
\text { Awal }\end{array}$} & Tinggi & 0,112 & 62 & 0,051 \\
\hline & & Rendah & 0,092 & 66 & 0,200 \\
\hline
\end{tabular}

Dari hasil uji Lilliefors Significance Correction dari Kolmogorov-Smirnov angka signifikansi pada kelompok siswa pembelajaran inkuiri terbimbing melalui laboratorium virtual didapat Sig 0,192, dan laboratorium riil Sig 0,059. Disimpulkan bahwa kedua data bersifat normal.

Grafik berikut menunjukkan normalitas data tersebut:

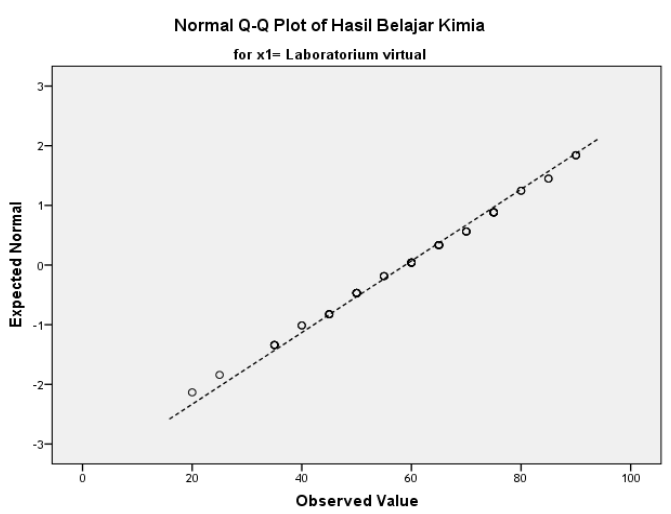

Gambar 1. Grafik Hasil Uji Normalitas berdasarkan Media Pembelajaran Laboratorium Virtuil Normal Q-Q Plot of Hasil Belajar Kimia for $\times 1=$ Lboratorium riil

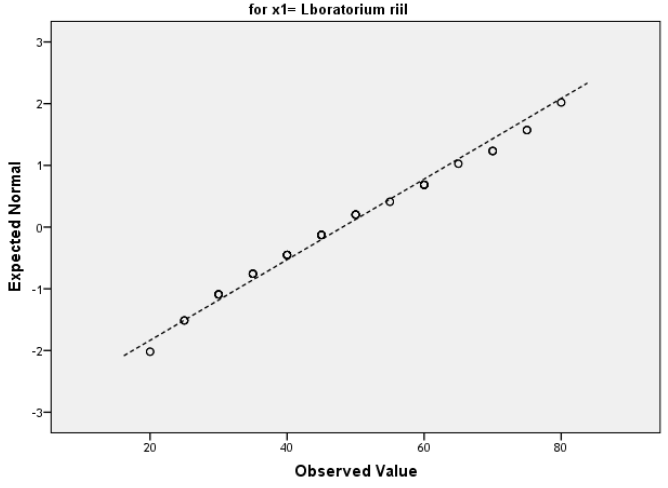

Gambar 2. Grafik Hasil Uji Normalitas berdasarkan Media Pembelajaran Laboratorium Riil

Uji Lilliefors Significance Correction dari Kolmogorov-Smirnov diperoleh signifikansi pada kelompok siswa gaya belajar visual Sig 0,067>0,05, dan kelompok siswa gaya belajar kinestetik Sig $0,200>0,05$. Kedua data bersifat normal.

Grafik berikut menunjukkan normalitas data tersebut. 


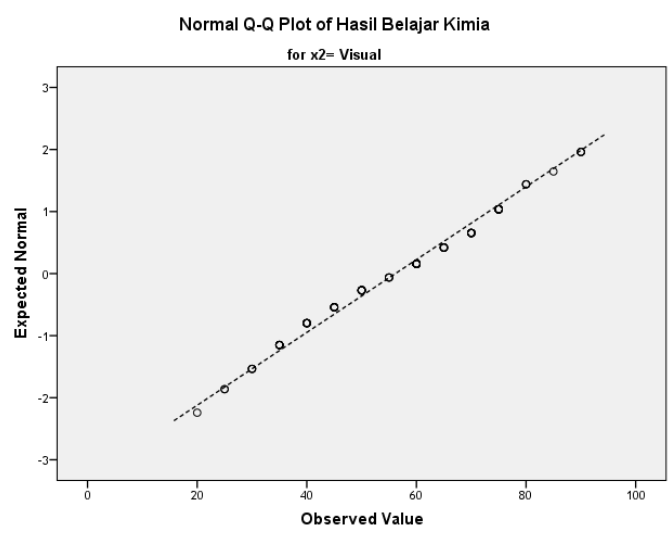

Gambar 3. Grafik Hasil Uji Normalitas berdasarkan Gaya Belajar Visual

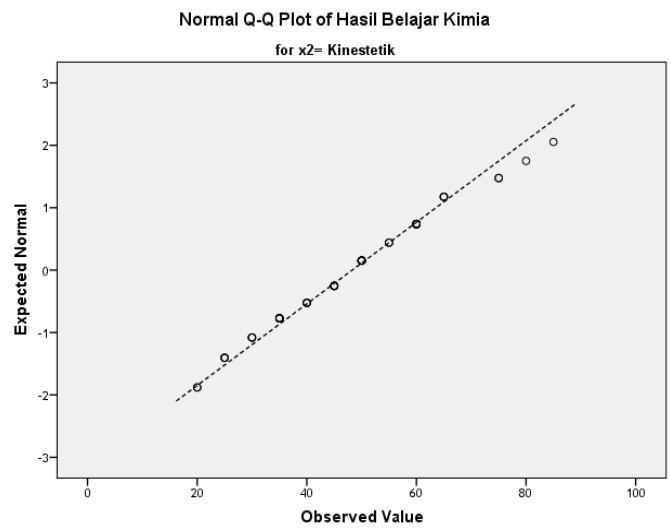

Gambar 4. Grafik Hasil Uji Normalitas berdasarkan Gaya Belajar Kinestetik

Uji Lilliefors Significance Correction dari Kolmogorov-Smirnov diperoleh kelompok siswa kemampuan awal tinggi didapat Sig 0,051>0,05, dan kelompok siswa kemampuan awal rendah didapat Sig $0,200>0,05$. Disimpulkan bahwa kedua data bersifat normal.

Grafik berikut menunjukkan normalitas data kedua kelompok tersebut.

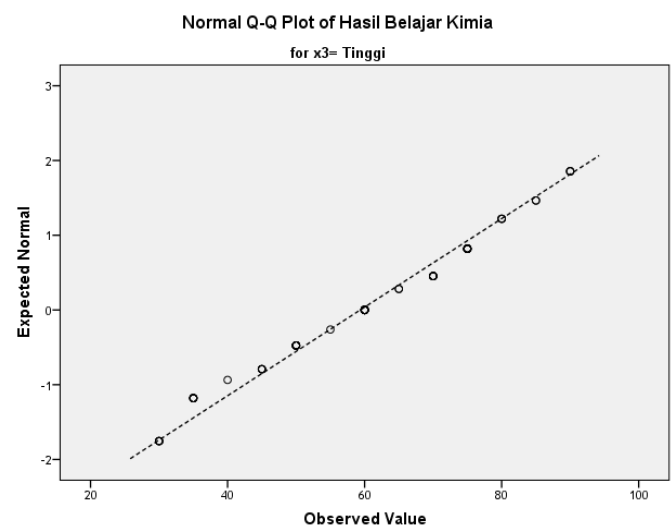

Gambar 5. Grafik Hasil Uji Normalitas berdasarkan Kemampuan Awal Tinggi

Normal Q-Q Plot of Hasil Belajar Kimia

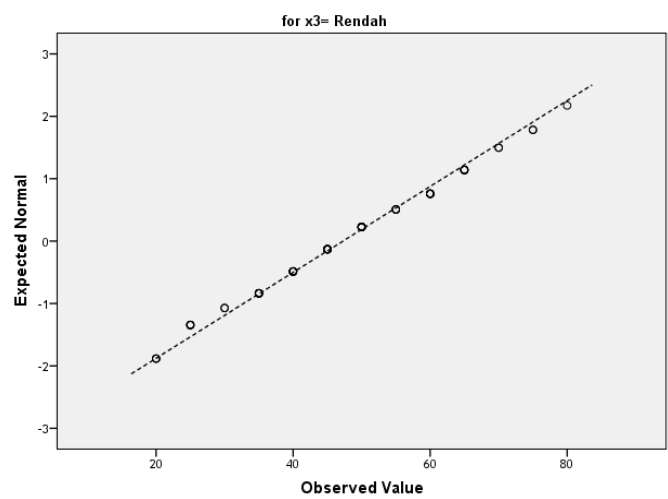

Gambar 6. Grafik Hasil Uji Normalitas berdasarkan Kemampuan Awal Rendah

2. Hasil Uji Homogenitas Data : Pengujian homogenitas data dilakukan melalui pengujian homogenitas variansi sampel dengan menggunakan uji Lavene dengan tingkat signifikansi 0,05, program SPSS release 10 .

Hasil pengujian homogenitas data prestasi belajar siswa pada tabel berikut ini :

Tabel 4. Hasil Uji Homogenitas Data Hasil Belajar 'Levene's Test of Equality of Error Variances'

\begin{tabular}{|c|c|c|c|c|}
\hline Design & $\mathrm{F}$ & df1 & df 2 & Sig \\
\hline $\begin{array}{l}\text { Intercept + Media + Gaya } \\
\text { Belajar+Kemampuan } \\
\text { Awal+Media Vs Gaya } \\
\text { Belajar+Media Vs } \\
\text { Kemampuan Awal+Gaya } \\
\text { Belajar Vs Kemampuan } \\
\text { Awal+ Media Vs Gaya } \\
\text { Belajar Vs Kemampuan } \\
\text { Awal }\end{array}$ & 1,47 & 7 & 120 & 0,184 \\
\hline
\end{tabular}

Hasil hitung statistik Lavene's diperoleh signifikansi 0,184. Dengan df (7:120) diperoleh bahwa nilai signifikansi hitung $0,184>0,05$, homogenitas data terpenuhi.

\section{A. Hasil Uji Hipotesis :}

Dari hasil perhitungan data dengan menggunakan analisis varians (Anava) tiga jalur untuk menguji hipotesis penelitian diperoleh data sebagai berikut :

Tabel 5. Hasil Uji Anava Antar Subyek Penelitian 
JURNAL INKUIRI

ISSN: 2252-7893, Vol. 7, No. 1, 2018 (hal 39-48)

http://jurnal.uns.ac.id/inkuiri

\begin{tabular}{|c|c|c|c|c|c|c|}
\hline No & Source & $\begin{array}{l}\text { Type III } \\
\text { Sum of } \\
\text { Square }\end{array}$ & Df & $\begin{array}{l}\text { Mean } \\
\text { Square }\end{array}$ & $\mathrm{F}$ & $\begin{array}{l}\mathrm{Si} \\
\mathrm{g}\end{array}$ \\
\hline 1 & $\begin{array}{l}\text { Correct } \\
\text { ed } \\
\text { Model }\end{array}$ & $\begin{array}{c}10706,83 \\
4^{\mathrm{a}}\end{array}$ & 7 & $\begin{array}{c}1529,5 \\
48\end{array}$ & $\begin{array}{c}7,32 \\
9\end{array}$ & $\begin{array}{l}0,0 \\
00\end{array}$ \\
\hline 2 & $\begin{array}{l}\text { Interce } \\
\mathrm{pt}\end{array}$ & $\begin{array}{c}333938,7 \\
55\end{array}$ & 1 & $\begin{array}{l}33393 \\
8,755\end{array}$ & $\begin{array}{l}1600 \\
, 143 \\
\end{array}$ & $\begin{array}{l}0,0 \\
00 \\
\end{array}$ \\
\hline 3 & $\begin{array}{l}\text { Media } \\
\text { Pembel } \\
\text { ajaran }\end{array}$ & 4039,972 & 1 & $\begin{array}{l}4039,9 \\
72\end{array}$ & $\begin{array}{c}19,3 \\
58\end{array}$ & $\begin{array}{c}0,0 \\
00\end{array}$ \\
\hline 4 & $\begin{array}{l}\text { Gaya } \\
\text { Belajar }\end{array}$ & 2073,735 & 1 & $\begin{array}{c}2073,7 \\
35 \\
\end{array}$ & $\begin{array}{c}9,93 \\
7 \\
\end{array}$ & $\begin{array}{l}0,0 \\
02 \\
\end{array}$ \\
\hline 5 & $\begin{array}{l}\text { Kema } \\
\text { mpuan } \\
\text { Awal }\end{array}$ & 4153,291 & 1 & $\begin{array}{c}4153,2 \\
91\end{array}$ & $\begin{array}{c}19,9 \\
01\end{array}$ & $\begin{array}{l}0,0 \\
00\end{array}$ \\
\hline 6 & $\begin{array}{l}\text { Media } \\
\text { Vs } \\
\text { Gaya } \\
\text { Belajar }\end{array}$ & 149,72 & 1 & 149,72 & $\begin{array}{c}0,71 \\
7\end{array}$ & $\begin{array}{l}0,3 \\
99\end{array}$ \\
\hline 7 & $\begin{array}{l}\text { Media } \\
\text { Vs } \\
\text { Kema } \\
\text { mpuan } \\
\text { Awal }\end{array}$ & ,000 & 1 & ,000 & 000 & $\begin{array}{l}0,9 \\
99\end{array}$ \\
\hline 8 & $\begin{array}{l}\text { Gaya } \\
\text { Belajar } \\
\text { Vs } \\
\text { Kema } \\
\text { mpuan } \\
\text { Awal } \\
\end{array}$ & 85,104 & 1 & 85,104 & $\begin{array}{c}0,40 \\
8\end{array}$ & $\begin{array}{l}0,5 \\
24\end{array}$ \\
\hline 9 & $\begin{array}{l}\text { Media } \\
\text { Vs } \\
\text { Gaya } \\
\text { Belajar } \\
\text { Vs } \\
\text { Kema } \\
\text { mpuan } \\
\text { Awal } \\
\end{array}$ & 0,139 & 1 & 0,139 & $\begin{array}{c}0,00 \\
1\end{array}$ & $\begin{array}{l}0,9 \\
79\end{array}$ \\
\hline 10 & Error & $\begin{array}{c}25043,16 \\
6 \\
\end{array}$ & 120 & $\begin{array}{c}208,69 \\
3 \\
\end{array}$ & & \\
\hline 11 & Total & 397000 & 128 & & & \\
\hline 12 & $\begin{array}{l}\text { Correct } \\
\text { ed } \\
\text { Total }\end{array}$ & 35750 & 127 & & & \\
\hline
\end{tabular}

1. Pengujian Hipotesis Pertama

\begin{tabular}{ccccc}
\hline Deskripsi & \multicolumn{2}{c}{ Statistik } & \multicolumn{2}{c}{ Std Error } \\
\hline & Lab & Lab & Lab & Lab Riil \\
& Virtuil & Riil & Virtuil & La \\
\hline Mean & & & & \\
& $\mathbf{5 8 , 8 3 0}$ & $\mathbf{4 8 , 0 9 0}$ & $\mathbf{2 , 1 5 0}$ & $\mathbf{1 , 8 5 6}$ \\
\hline
\end{tabular}

Harga $F_{\text {hitung }}=19,358$ dengan taraf signifikansi $\alpha=0,00<\alpha=0,05 . . \quad$ Prestasi belajar kelompok siswa yang belajar dengan menggunakan laboratrium virtual 58,830 lebih tinggi dari kelompok siswa yang belajar dengan menggunakan laboratorium riil 48,090.

2. Pengujian Hipotesis Kedua

\begin{tabular}{lll}
\hline Deskripsi & Statistik & Std \\
\hline
\end{tabular}


Harga $\quad F_{\text {hitung }}=0,408$ dengan taraf signifikansi $\alpha=0,524>0,05$ berarti tidak ada interaksi yang signifikan antara gaya belajar dan kemampuan awal.Siswa yang memiliki kemampuan awal tinggi, gaya belajar visual maupun kinestetik pencapaian hasil belajarnya lebih tinggi dari siswa yang memiliki kemampuan awal rendah,

7. Pengujian Hipotesis Ketujuh

Harga $F_{\text {hitung }}=0,001$ dengan taraf signifikansi $\alpha=0,979>0,05$, berarti tidak ada interaksi yang signifikan antara strategi

Tabel 6. Data Hasil Uji Lanjut Anava (Estimates dan Pairwise Comparison)

\begin{tabular}{|c|c|c|c|c|c|c|c|c|c|c|c|c|}
\hline \multirow{3}{*}{\multicolumn{3}{|c|}{ Variabel }} & \multicolumn{5}{|c|}{ Estimates } & \multicolumn{5}{|c|}{ Pairwise Comparison } \\
\hline & & & \multirow{2}{*}{\multicolumn{2}{|c|}{ Mean }} & \multirow{2}{*}{$\begin{array}{l}\text { Std } \\
\text { error }\end{array}$} & \multicolumn{2}{|c|}{ 95\% Confidence Interval } & \multirow{2}{*}{$\begin{array}{c}\text { Mean } \\
\text { Differe } \\
\text { nce (I- } \\
\mathrm{J}) \\
\end{array}$} & \multirow{2}{*}{$\begin{array}{l}\text { Std } \\
\text { Error }\end{array}$} & \multirow[b]{2}{*}{ Sig } & \multicolumn{2}{|c|}{ 95\% Confidence Interva } \\
\hline & & & & & & $\begin{array}{l}\text { Lower } \\
\text { Bound }\end{array}$ & $\begin{array}{l}\text { Upper } \\
\text { Bound } \\
\end{array}$ & & & & $\begin{array}{l}\text { Lower } \\
\text { Bound } \\
\end{array}$ & $\begin{array}{l}\text { Upper } \\
\text { Bound } \\
\end{array}$ \\
\hline \multicolumn{3}{|c|}{ Lab. Virtuil } & & 58,451 & 1,905 & 54,680 & 62,222 & $\overline{-}, \overline{584}$ & 2,633 &, 000 & $-16,797$ & $-6,371$ \\
\hline \multicolumn{3}{|c|}{ Lab. Riil } & & 46,867 & 1,818 & 43,268 & 50,466 & $11,584^{*}$ & 2,633 &, 000 & 6,371 & 16,797 \\
\hline \multicolumn{3}{|c|}{ Gaya Belajar Visual } & & 56,809 & 1,633 & 53,575 & 60,043 & $-8,299^{*}$ & 2,633 &, 002 & $-13,512$ & $-3,087$ \\
\hline \multicolumn{3}{|c|}{ Gaya Belajar Kinestetik } & & 48,510 & 2,065 & 44,421 & 52,598 & $8,299^{*}$ & 2,633 &, 002 & $\mathbf{3 , 0 8 7}$ & 13,512 \\
\hline \multicolumn{3}{|c|}{$\begin{array}{c}\text { Kemampuan Awal } \\
\text { Tinggi }\end{array}$} & & $\mathbf{5 8 , 5 3 2}$ & 1,887 & 54,795 & 62,269 & $\overline{11,745^{*}}$ & 2,633 & ,000 & $-16,958$ & $-6,533$ \\
\hline \multicolumn{3}{|c|}{ Kemampuan Awal } & & 46,787 & 1,836 & 43,152 & 50,421 & $11,745^{*}$ & 2,633 &, 000 & 6,533 & 16,958 \\
\hline \multicolumn{7}{|c|}{$\begin{array}{l}\text { Tabel 7. Data Hasil "Univariate Tests" } \\
\text { Berdasarkan Hasil "Pairwise Comparison" }\end{array}$} & \multirow{2}{*}{\multicolumn{6}{|c|}{$\begin{array}{l}\text { belajar visual } 56,809 \text { lebih tinggi dari siswa } \\
\text { gaya belajar kinestetik } 48,510 \text {. } \\
\text { Uji lanjut pengaruh kemampuan awal, rata- } \\
\text { rata prestasi belajar siswa kemampuan awal } \\
\text { tinggi } 58,532 \text { lebih tinggi dari siswa } \\
\text { kemampuan awal rendah 48,510. }\end{array}$}} \\
\hline $\begin{array}{l}\text { Variab } \\
\text { el }\end{array}$ & $\begin{array}{c}\text { Univ } \\
\text { ariat } \\
\mathrm{e} \\
\text { Test } \\
\mathrm{s} \\
\end{array}$ & $\begin{array}{l}\text { Sum } \\
\text { of } \\
\text { Squar } \\
\text { e }\end{array}$ & Df & $\begin{array}{l}\text { Mean } \\
\text { Squar } \\
\text { e }\end{array}$ & $\mathrm{F}$ & Sig & & & & & & \\
\hline
\end{tabular}

\begin{tabular}{llrrrrr}
\hline & \multicolumn{1}{c}{ S } & & & $\mathbf{4 , 0 3 9}$ & $\mathbf{1 9 , 3 5}$ & \\
\multirow{2}{*}{$\begin{array}{l}\text { Media } \\
\text { Pembel }\end{array}$ Cont } & $\mathbf{4 , 0 3 9 ,}$ & $\mathbf{9 7}$ & $\mathbf{9 7 2}$ & $\mathbf{8}$ & $\mathbf{, 0 0 0}$ \\
\cline { 2 - 7 } ajaran & Erro & $\mathbf{2 5 , 0 4}$ & $\mathbf{1 2}$ & $\mathbf{2 0 8 , 6}$ & & \\
& r & $\mathbf{3 , 1 6 6}$ & $\mathbf{0}$ & $\mathbf{9 3}$ & & \\
\hline \multirow{3}{*}{ Gaya } & Cont & $\mathbf{2 , 0 7 3 ,}$ & & $\mathbf{2 , 0 7 3}$ & & \\
Belajar & rast & $\mathbf{7 3 5}$ & $\mathbf{1}$ & $\mathbf{, 7 3 5}$ & $\mathbf{9 , 9 3 7}$ & $\mathbf{, 0 0 2}$ \\
\cline { 2 - 7 } & Erro & $\mathbf{2 5 , 0 4}$ & $\mathbf{1 2}$ & $\mathbf{2 0 8 , 6}$ & & \\
& r & $\mathbf{3 , 1 6 6}$ & $\mathbf{0}$ & $\mathbf{9 3}$ & & \\
\hline \multirow{2}{*}{ Kema } & Cont & $\mathbf{4 , 1 5 3 ,}$ & & $\mathbf{4 , 1 5 3}$ & $\mathbf{1 9 , 9 0}$ & \\
mpuan & rast & $\mathbf{2 9 1}$ & $\mathbf{1}$ & $\mathbf{2 9 1}$ & $\mathbf{1}$ & $\mathbf{, 0 0 0}$ \\
\cline { 2 - 7 } Awal & Erro & $\mathbf{2 5 , 0 4}$ & $\mathbf{1 2}$ & $\mathbf{2 0 8 , 6}$ & & \\
& r & $\mathbf{3 , 1 6 6}$ & $\mathbf{0}$ & $\mathbf{9 3}$ & & \\
\hline
\end{tabular}

Uji lanjut media pembelajaran diperoleh Sig $0,000<0,05$. Rata-rata prestasi belajar siswa yang menggunakan media laboratorium virtual 58,451 lebih tinggi dari siswa yang menggunakan labortorium riil 46,867.

Uji lanjut gaya belajar diperoleh Sig 0,020 $<0,05$. Rata-rata prestasi belajar siswa gaya pembelajaran, gaya belajar siswa dan kemampuan awal.

\section{B. Hasil Uji Lanjut Anava}

Uji lanjut Anava terhadap variable yang berpengaruh, yakni uji one way Anava dengan menggunakan model Befferoni.

\section{Kesimpulan dan Rekomendasi}

Kesimpulan dari hasil ananlisis data :

1. Siswa yang belajar dengan pembelajaran inkuiri terbimbing melalui laboratorium virtual prestasi belajar lebih tinggi daripada siswa inkuiri terbimbing menggunakan laboratorium riil,

2. Siswa gaya belajar visual memiliki prestasi belajar lebih tinggi daripada siswa gaya belajar kinestetik,

3. Siswa kemampuan awal tinggi memiliki prestasi belajar lebih tinggi daripada siswa kemampuan awal rendah,

4. Tidak ada interaksi antara pembelajaran dengan model inkuiri terbimbing menggunakan media pembelajaran 
laboratorium virtual dan laboratorium riil dengan gaya belajar siswa,

5. Tidak ada interaksi antara penggunaan media pembelajaran laboratorium virtual dan laboratorium riil dengan kemampuan awal siswa,

6. Tidak ada interaksi antara gaya belajar siswa dengan kemampuan awal siswa,

7. Tidak ada interaksi antara penggunaan media pembelajaran laboratorium virtual dan laboratorium riil, gaya belajar dan kemampuan awal siswa,

Penggunaan laboratorium virtuil dan laboratorium riil dapat digunakan secara bersama dalam satu materi pembelajaran. Model pembelajaran inkuiri terbimbing dapat diterapkan untuk materi Larutan Buffer dan Hidrolisis Garam. Besarnya pengaruh penggunaan media laboratorium, gaya belajar dan kemampuan awal tidak hanya diukur dari kemampuan kognitif saja melainkan juga kemampuan sikap dan ketrampilan kerja di laboratorium.

Oleh karena itu perlu dilakukan penelitian untuk pembelajaran materi Larutan Buffer dan Hidrolisis Garam dengan model inkuiri terbimbing menggunakan media laboratorium riil. Hasil percobaan digunakan untuk menyimpulkan adanya larutan yang dapat mempertahankan $\mathrm{pH}$ pada penambahan asam atau basa. Selanjutnya media laboratorium virtual digunakan untuk membantu siswa menjawab pertanyaan, mengapa larutan buffer bisa mempertahankan pHnya pada penambahan asam atau basa. Kemampuan yang diukur meliputi kemampuan kognitif, sikap dan ketrampilan.

Dalam hal ini penelitian berkisar pada efektivitas penggunaan media laboratorium riil dan virtual pada pembelajaran materi Larutan Buffer dan Hidrolisis Garam dengan model inkuiri terbimbing/terarah.

\section{Daftar Pustaka}

Abdi, A., 2014. The Effect of Inquiry - Based Learning Method on Students' Academic Achievement in Science Course. Universal
Journal of Educational Research, vol 2(1), hlm. 37-41.

Abidin, M.J.Z., Rezaee, A.A., Abdullah, H.N., Singh, K.K.B., 2011. Learning Styles and Overall Academic Achievment in a Specific Educational System. Internotional Journal of Humanities and Social Science, vol 1(10), hlm. 143-152

Aksela, M. dan Bostrom, M., 2012. Supporting Students' Interest Through Inquiry-Based Learning in the Contextof Fuel Cells. Mevlana International Journal of Education. Vol 2(3), hlm. 53-61.

Arikunto, Suharsimi, 1987, Dasar-dasar Evaluasi Pendidikan, Yogyakarta: Bumi Aksara

Ashadi, 2009, Hand Out: Mata Kuliah Statistik program Pasca Sarjana, Surakarta: Program Studi Pendidikan Sains Pasca Sarjana, Universitas Sebelas Maret

Bayram, Z., Oskay, O.O., Erdem, E., Ozgur, S.D., Sen, S. 2013. Effect of Inquiry Based Learning Method on Student' Motivation. Procedia-Social and Behavioral Sciences, edisi 106, hlm. 988-996.

Depdiknas, 2004, Kurikulum KTSP 2008, dan Pengembangan Sylabus, Mata Pelajaran Kimia, Jakarta : Depdiknas

Exlin, Joe,2004, What Is Inqiry based learning, Educatuinal Broadcasting Corporation, Allroght reservedn, http://www,thirteen org/edonline/concept 2class/inkuiri/, Diunduh Tanggal 31 Desember 2008

Franzoni, A.L. dan Assar, S., 2009. Studen Learning Styles Adaption Method Based on Teaching Strategies and Electronic Media. Educational Tecnology \& Society, vol 12(4), hlm. 15-29.

Garton, Janetta,, 2005, Inkuiri-Based Learning, Willard R-II School District, Technology Integration Academy.

Gilakjani, A.P., 2012. Visual, Auditory. Kinesthetic Learning Styles and Their Impacts on English Language Teaching. Journal of Studies in Education, vol 2(1), hlm. 104111

Gilbert, J.E. dan Swanier, C.A., 2008. Lerning Stelist : How Do They Fluctuate ? Institute for Learning Styles Journal, vol 1, hlm. 29-37 
Gormally, C., Brickman, P., Hallar, B., Armstrong, N., 2009. Effects of Inquiry-Based Learning on Students' Science Literacy Skills and Confidence. International Journal for the Scholarship of Teaching and Learning. Vol 3(2), hlm. 11-22

Harsanto, Radno, 2005, Melatih Anak Berfikir Analitis, Kritis, Dan Kreatif, Jakarta : Grasondo

Haury, L, David, (1993), Teaching Science Through Inkuiri, Columbus, OH: ERIC Clearinghouse for Science, Mathematics, and Environment Education, (ED359048)

Huitt, W, (1997), Socioemotional development, Educational Psychology Interactive, Valdosta, GA: Valdosta State University

Justiana, Sandri dan Muchtaridi, 2009, Chemistry For High School, third edition, Jakarta: Yudhistira,

Kilinc, Ahmed 2007, The Opinions of Turkish Highschool Pupils On Inkuiri Based Laboratory Activities, The Turkish Online Journal Of Education - TOJET, Volume (6), Issue (4), Article (6), Tersedia www, TOJET, Net, Diunduh tanggal $16 \mathrm{Mei}$ 2009

Purba, Michael, 2004, Kimia untuk SMA kelas XI, Jakarta: Erlangga

Quitadamo,IJ, Faiola, C,L, Johnson, J,E \&Kurtz, $\mathrm{M}, \mathrm{J}, 2008$, Community Based Inkuiri Improves Critical Thinking in GeneralEducation Biology, http://scholar ,lib,vt,edu/ejournals/JTE/jtev7n1/gokhale,Life Sciences Education, Volume (7), April 2008, Diunduh Tanggal 8 Nopember 2008

Rankin,, Lynn, 2000, Lesson Learned :Addressing Cammon Misconptions About Inkuiri, http://www,nsf,gov/pubs/2000/nsf99148/c h 5,htm, Diunduh Tanggal 22 Oktober 2008

Rooney, C., 2009. How am I Using Inquiry-Based Learning to Improve My Practice and to Enchourage Higher Order Thinking among My Students of Mathematics? Educational Journal of Living Theories, vol 5(2), hlm. 99-127.
Sunarno, Widha. 2009, Hand out : Mata Kuliah Metodologi Penelitian Pendidikan Sains, Surakarta : Program Studi Pendidikan Sains Pasca Sarjana, Universitas Sebelas Maret

Suparno, Paul, 2006, Metodologi Pembelajaran Fisika, Konstruktif dan Menyenangkan, Yogyakarta : Universitas Sanata Dharma

Trna, J., Trnova, E., Sibor, J., Implementation of Inquiry-Based Science Education in Science Teacher Training. Journal of Education and Instructional Studies in the World. Vol 2. Hlm. 199-207.

Winkel, S., Psikologi Pengajaran, Jakarta: Grasin 